\title{
Reaction of Select Tepary Bean to Bean Golden Mosaic Virus
}

\author{
Phillip N. Miklas ${ }^{1}$ and Jose Santiago \\ U.S. Department of Agriculture, Agricultural Research Service, Tropical \\ Agriculture Research Station, P.O. Box 70, Mayagüez, PR 00681
}

Additional index words. disease tolerance, Phaseolus acutifolius, interspecific trait transfer

\begin{abstract}
Cultivated tepary bean (Phaseolus acutifolius A. Gray var. latifolius Freeman) has potential for production during the hot, dry seasons in the tropics. Bean golden mosaic virus (BGMV), however, seriously limits production of Phaseolus spp. in such environments. Twelve select tepary beans were evaluated for reaction to BGMV across four field nurseries near Isabela, Puerto Rico. Disease reaction was principally determined by

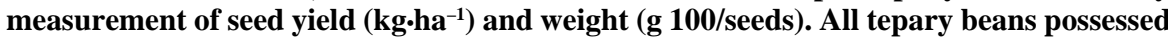
some tolerance to BGMV, as they produced comparatively moderate seed yield despite expression of severe foliar yellow mosaic symptoms. On average, tepary bean yielded $133 \%$ of the BGMV-resistant dry bean (Phaseolus vulgaris L.) control 'Dorado'. Four teparies, Neb-T-6-s, GN-610-s, Neb-T-8a-s, and PI 321637-s, expressed superior tolerance to BGMV as they yielded above the trial mean in at least three of four trials. Harvested seed quality was uniformly poor across all lines, averaging $18 \%$ less weight than in the nonBGMV trials. The combination of the observed tolerance with escape mechanisms and cultural disease control practices may enable production of tepary bean in regions and seasons that experience moderate to severe BGMV epidemics.
\end{abstract}

The cultivated tepary bean, an annual legume similar to dry bean, is indigenous to the Sonoran region of Mexico and the southwestern United States (Nabhan and Felger, 1978). Teparies are also grown in Central America where production is mostly limited to the arid coastal plains. Because of their domestication in these hot, dry environments, tepary bean is adapted to extreme heat and drought stress (Nabhan, 1979). For this reason, tepary bean has received considerable attention as a potential crop in arid regions around the world and in places with hot, dry seasons (e.g., some tropical regions). In addition, traits from tepary bean have been used to improve dry bean, as monogenic resistance to common bacterial blight caused by Xanthomonas campestris pv. phaseoli (Smith) Dye, and its transfer via interspecific hybridization using embryo rescue, has been well documented (Drijfhout and Blok, 1987; Honma, 1956; Parker and Michaels, 1986; Scott and Michaels, 1992).

Bean golden mosaic virus (BGMV) limits the yield of tepary bean on the coastal plains of Honduras and Nicaragua and is a major disease of common bean throughout the warmer regions of the Americas (Beebe and PastorCorrales, 1991). We sought to evaluate the potential for tepary bean to produce an ad-

\footnotetext{
Received for publication 25 Sept. 1995. Accepted for publication 23 Jan. 1996. The cost of publishing this paper was defrayed in part by the payment of page charges. Under postal regulations, this paper therefore must be hereby marked advertisement solely to indicate this fact.

${ }^{1}$ Current address: U.S. Dept. of Agriculture, Agricultural Research Service, Irrigated Agriculture Research and Extension Center, 24106 N. Bunn Rd., Prosser, WA 99350-9687; to whom reprint requests should be addressed.
}

equate seed crop during BGMV epidemics by screening a select group of high-yielding tropically adapted tepary beans (Miklas et al., 1994) for disease reaction to natural BGMV infection in the field.

\section{Materials and Methods}

Germplasm. Twelve tropically adapted tepary bean genotypes were evaluated for disease reaction to natural BGMV infection across four field environments. The 12 genotypes were Neb-T-1-s, Neb-T-6-s, Neb-T-8a-s, NebT-15-s, GN-605-s, GN-610-s, PIs 321637-s, 321638-s, 440788-s, 440806-s, 502217-s, and PI 312122-s. Their development and general characteristics were reported by Miklas et al. (1994). 'Dorado' (formerly DOR 364; Beebe and Pastor-Corrales, 1991) and 'ArroyoLoro', tropically adapted and high-yielding dry beans, were included as BGMV-resistant and -susceptible controls, respectively. The original accessions underwent single-plant and bulk selection to obtain tepary bean lines of more uniform agronomic type (maturity, seed color and shape, growth habit) and resistance to disease, particularly common bacterial blight (Miklas et al., 1994). All 12 lines exhibited adequate seed weight (>10 g 100/seed) and high yield potential across an array of tropical environments in Puerto Rico and Honduras, and some possessed uniform resistance to rust [Uromyces appendiculatus (Pers.) Unger var. appendiculatus] and powdery mildew (Erysiphe polygoni DC.) (Miklas et al., 1994).

Evaluations. Each entry (12 teparies and two dry bean controls) was planted at 160,000 seeds/ha in a randomized complete block with three replications. Plots were single rows, 1.0 m long. For the 1995 trial, the plot size was two rows, each $2 \mathrm{~m}$ long, and spacing between rows in both trials was $0.9 \mathrm{~m}$. Each plot repre- sented an experimental unit. Granular fertilizer $\left(\mathrm{kg} \cdot \mathrm{ha}^{-1}\right), 59 \mathrm{~N}-40 \mathrm{P}-2.3 \mathrm{~K}$, was sidedressed $\approx 18$ days after planting. A combination of preemergence herbicide and mechanical and hand cultivation was used to control weeds. Overhead irrigations were applied when needed. About 45 days after planting, combined disease incidence and severity was scored using a 1-9 scale (Morales and Singh, 1993; Schoonhoven and Pastor-Corrales, 1987), where the percentage of canopy with mosaic was $1=0 \%, 3=10 \%$ to $20 \%, 6=50 \%$ to $65 \%$, and $9=$ greater than $95 \%$. Once plots matured, they were combined using a stationary smallplot thresher. Seeds were dried in a mechanical air-flow oven for $48 \mathrm{~h}$ at $38 \mathrm{C}$ to equalize moisture content before cleaning (by handheld screens) and obtaining weights. After drying and cleaning the seed, yield $\left(\mathrm{kg} \cdot \mathrm{ha}^{-1}\right)$ and weight (g 100/seeds) were recorded for each plot.

Inoculation. Four BGMV field screening trials were conducted at the U.S. Dept. of Agriculture, Agricultural Research Service Research Farm near Isabela, Puerto Rico, during Spring (planted 16 Feb.), Summer (25 May), and Fall (28 Sept.) 1994, and late Spring (12 Apr.) 1995. To increase natural BGMV inocula, groups of three rows of 'Arroyo Loro' were sown first, on each side of, and every 20 $m$ within, the eventual experimental area. Once yellow mosaic symptoms were relatively uniform across these spreaders $(\approx 28$ days after planting), the tepary lines and dry bean controls were sown. The trials, excluding 1995, were contiguous and planted using a relay system, whereby spreaders for the new trial were planted beside the preceding trial as it approached physiological maturity. To promote movement of BGMV by the whitefly vector (Bemisia argentifolia and B. tabaci) across a new planting, seed were sown on the leeward side of the previous planting. Relaycropping in this manner maintained an adequate population of the vector and provided a reservoir of BGMV inoculum for each succeeding planting.

Analysis. The combined data across four BGMV trials were subjected to analysis of variance using the GLM procedure of SAS (SAS Inst., 1987). Homogeneity of error variance (Bartlett's test) was detected across experiments for each trait. Simple correlations $(r)$ were computed between mean seed yield and seed weight obtained across the BGMV trials of this study and non-BGMV-infected trials from a previous study (Miklas et al., 1994).

\section{Results and Discussion}

The tepary bean lines apparently possessed tolerance to BGMV, as they produced a moderate seed yield despite expression of severe foliar yellow mosaic symptoms (Tables 1 and $2)$. The 12 tepary bean lines varied in their tolerance to BGMV within and across environments, however, as evidenced by significant $(P<0.05)$ line and line $\times$ environment effects for seed yield and seed weight. Neb-T6-s, GN-610-s, Neb-T-8a-s, and PI 321637-s 
Table 1. Mean seed yield and bean golden mosaic virus (BGMV) score of 12 cultivated tepary bean and two dry bean controls grown across four BGMV field-screening nurseries near Isabela, Puerto Rico.

\begin{tabular}{|c|c|c|c|c|c|c|c|}
\hline \multirow[b]{3}{*}{ Line } & \multicolumn{7}{|c|}{ Yield $\left(\mathrm{kg} \cdot \mathrm{ha}^{-1}\right)$} \\
\hline & \multicolumn{3}{|c|}{1994} & \multirow{2}{*}{$\frac{1995}{\text { Summer }}$} & \multirow{2}{*}{$\begin{array}{c}\text { Disease } \\
\text { mean }\end{array}$} & \multirow{2}{*}{$\begin{array}{c}\text { Nondisease } \\
\text { mean }^{z}\end{array}$} & \multirow{2}{*}{$\begin{array}{r}\text { BGMV } \\
\text { score }^{y}\end{array}$} \\
\hline & Spring & Summer & Fall & & & & \\
\hline \multicolumn{8}{|l|}{ Tepary bean } \\
\hline Neb-T-6-s & 832 & 1262 & 251 & 547 & 723 & 1450 & 7.8 \\
\hline GN-610-s & 1108 & 628 & 108 & 682 & 632 & 1368 & 7.8 \\
\hline Neb-T-8a-s & 1087 & 1040 & 145 & 221 & 623 & 1389 & 8.4 \\
\hline PI 321637-s & 615 & 1236 & 188 & 375 & 604 & 1010 & 8.6 \\
\hline Neb-T-1-s & 606 & 746 & 36 & 751 & 535 & 1328 & 8.0 \\
\hline PI 502217-s & 915 & 703 & 66 & 290 & 493 & 1339 & 7.9 \\
\hline GN-605-s & 760 & 827 & 52 & 169 & 452 & 1052 & 7.8 \\
\hline Neb-T-15-s & 692 & 565 & 30 & 493 & 445 & 1276 & 8.1 \\
\hline PI 440788-s & 931 & 393 & 29 & 173 & 381 & 1348 & 7.3 \\
\hline PI 312122-s & 574 & 823 & 64 & 115 & 394 & --- & 8.1 \\
\hline PI 440806-s & 574 & 696 & 93 & 87 & 363 & 1158 & 8.3 \\
\hline PI 321638-s & 841 & 414 & 52 & 74 & 345 & 1329 & 7.2 \\
\hline \multicolumn{8}{|c|}{ Dry bean controls } \\
\hline Dorado & 536 & 301 & 398 & 265 & 375 & --- & 4.1 \\
\hline Arroyo Loro & 120 & 45 & 81 & 9 & 64 & --- & 7.3 \\
\hline Mean $^{x}$ & 728 & 691 & 114 & 303 & 461 & --- & 7.6 \\
\hline $\operatorname{LSD}_{(0.05)}$ & 352 & 321 & 96 & 323 & 143 & --- & 0.7 \\
\hline $\mathrm{CV} \%$ & 63 & 29 & 28 & 50 & 38 & --- & 11.2 \\
\hline
\end{tabular}

${ }^{2}$ Mean seed yield averaged across six non-BGMV-infected field trials (Miklas et al., 1994).

${ }^{y}$ Average disease (1-9) score obtained across the four environments, where the percentage of canopy with mosaic was: $1=0 \%, 3=10 \%$ to $20 \%, 6=50 \%$ to $65 \%$, and $9=$ greater than $95 \%$ (Morales and Singh, 1993; Schoonhoven and Pastor-Corrales, 1987).

${ }^{x}$ Additional LSDS $(P \leq 0.05)$ for the combined analysis of seed yield across four BGMV trials: environment $=76$; line $\times$ environment $=86$. Trial means include the dry bean controls .

Table 2. Mean seed weight of 12 cultivated tepary bean and two dry bean controls grown across four bean golden mosaic virus field-screening nurseries near Isabela, Puerto Rico.

\begin{tabular}{|c|c|c|c|c|c|c|}
\hline \multirow[b]{3}{*}{ Line } & \multicolumn{6}{|c|}{ Seed wt (g 100/seeds ) } \\
\hline & \multicolumn{3}{|c|}{1994} & 1995 & \multirow{2}{*}{$\begin{array}{c}\text { Disease } \\
\text { mean }\end{array}$} & \multirow{2}{*}{$\begin{array}{c}\text { Nondisease } \\
\text { mean }^{z}\end{array}$} \\
\hline & Spring & Summer & Fall & $\overline{\text { Summer }}$ & & \\
\hline \multicolumn{7}{|l|}{ Tepary bean } \\
\hline PI 321637-s & 15.7 & 10.3 & 11.8 & 10.5 & 12.1 & 13.3 \\
\hline PI 440806-s & 15.8 & 10.0 & 9.9 & 11.7 & 11.8 & 12.8 \\
\hline Neb-T-6-s & 13.8 & 9.8 & 9.8 & 10.2 & 10.9 & 13.8 \\
\hline GN-610-s & 15.3 & 9.7 & 9.1 & 9.7 & 10.9 & 12.7 \\
\hline PI 502217-s & 15.2 & 8.8 & 9.2 & 9.7 & 10.7 & 13.4 \\
\hline Neb-T-8a-s & 14.3 & 9.3 & 10.4 & 8.4 & 10.6 & 13.0 \\
\hline PI 440788-s & 14.8 & 8.2 & 7.8 & 9.0 & 10.0 & 12.0 \\
\hline Neb-T-15-s & 13.2 & 8.5 & 8.7 & 9.7 & 10.0 & 13.8 \\
\hline PI 312122-s & 11.7 & 8.5 & 8.9 & 10.7 & 9.9 & --- \\
\hline Neb-T-1-s & 12.7 & 8.0 & 9.1 & 8.5 & 9.6 & 10.7 \\
\hline GN-605-s & 11.8 & 7.0 & 6.7 & 9.3 & 8.7 & 10.7 \\
\hline PI 321638-s & 12.5 & 6.5 & 7.0 & 7.8 & 8.4 & 11.0 \\
\hline \multicolumn{7}{|l|}{ Dry bean } \\
\hline Dorado & 17.0 & 13.5 & 14.2 & 15.2 & 15.0 & --- \\
\hline Arroyo Loro & 14.0 & 11.0 & 12.2 & 13.4 & 12.6 & --- \\
\hline Mean ${ }^{y}$ & 14.1 & 9.2 & 9.6 & 10.2 & 10.8 & --- \\
\hline $\operatorname{LSD}_{(0.05)}$ & 1.3 & 0.9 & 1.6 & 0.9 & 0.6 & --- \\
\hline $\mathrm{CV} \%$ & 6.8 & 6.2 & 9.7 & 5.2 & 7.2 & --- \\
\hline
\end{tabular}

${ }^{2}$ Mean seed weight averaged across five non-BGMV-infected field trials (Miklas et al., 1994).

${ }^{y}$ Additional LSDS $(P \leq 0.05)$ for the combined analysis across four BGMV trials: environment $=0.3$; line $\times$ environment $=1.3$. Trial means include the dry bean controls.

were the most tolerant lines across environments. The line $x$ environment interactions suggest that multiple environment testing is necessary to identify those tepary bean lines with the greatest tolerance to BGMV.

Severe disease pressure occurred in all four trials as evidenced by low seed yields and intermediate disease scores for the BGMVresistant control 'Dorado' and extremely low yields and high disease scores for the susceptible control 'Arroyo Loro' (Table 1). Tepary bean seed yields averaged $133 \%$ of the resistant dry bean 'Dorado' across all four trials. Only in the fall trial (1994) did tepary bean average less yield than 'Dorado'. Although tepary bean lines exhibited severe foliar yellow mosaic, they did not possess the susceptible symptoms (Galvez and Morales, 1989) of severely twisted and deformed pods, and low seed yield, as is usually characteristic of dry bean germplasm not previously selected for resistance to BGMV. The 12 tepary bean lines thus showed a mechanism similar to the dry beans 'Honduras 46' and DOR 316 for tolerance to BGMV (Beebe and Pastor-Corrales, 1991), i.e., moderate seed yield despite severe foliar yellow mosaic symptoms.

The BGMV-induced yield reduction of Neb-T-6-s, GN-610-s, Neb-T-8a-s, and PI 321637-s, as deduced from seed yields from
non-BGMV-infected trials in a previous study that involved 11 of the same lines (Miklas et al., 1994), was the lowest among the genotypes and ranged from $40 \%$ to $55 \%$. The yield reduction of the seven remaining lines in the previous study ranged from $57 \%$ to $74 \%$. The low ( $r=0.27,9 \mathrm{df}$, Ns) correlation between mean seed yields from the diseased and nondiseased trials (Miklas et al., 1994) also reflected the differential seed yield response of tepary bean to BGMV infection. In the present study, Neb-T-1-s, GN-605-s, Neb-T15-s, and PIs 312122-s, 321638-s, 440788-s, 440806-s, and 502217-s appeared to possess relatively intermediate levels of tolerance to BGMV because they averaged about the same yield across environments as did the BGMVresistant dry bean 'Dorado'.

Although moderate seeds yields in the presence of severe mosaic symptoms were achieved, the quality of the harvested seed was poor. Seed weights (g 100/seeds) across tepary bean lines (Table 2) were $83 \%$ of those observed across non-BGMV trials in a previous study (Miklas et al., 1994). The apparent reduction in seed weight of tepary bean resulting from BGMV infection was slightly less than that which occurred for the dry bean controls 'Dorado' (74\%) and 'Arroyo Loro' (79\%). A significant correlation between average seed weight from infected and noninfected trials $(r$ $=0.77,9 \mathrm{df}, P \leq 0.01)$ indicates that the amount of reduction in seed weight due to BGMV was relatively uniform across lines. Moreover, this correlation suggests that the differential reduction in seed yield among lines described above results more from differences in the number of seeds harvested than differential reduction of the mean weight of harvested seeds.

If tolerance to BGMV is quantitatively controlled, then transfer of this trait to dry bean via interspecific hybridization will be extremely difficult. The tolerance expressed by the dry bean 'Honduras 46' has been readily transferred intraspecifically and suggests that interspecific transfer of BGMV tolerance is possible. PI 321638, the tepary line least tolerant to BGMV, is known to produce semifertile interspecific lines when crossed with $P$. vulgaris (Thomas and Waines, 1984). The four most tolerant lines (Neb-T-6-s, GN-610s, Neb-T-8a-s, and PI 321637-s) may not combine with dry bean as readily as PI 321638, posing another challenge to the interspecific transfer of BGMV tolerance.

Tolerance to BGMV alone will not ensure successful production of tepary bean in the hot, dry seasons in the tropics where they are best adapted (Miklas et al., 1994), because BGMV epidemics in those environments can be extremely severe. Integrated management practices that combine tolerance with escape mechanisms (e.g., early maturity) and cultural practices (e.g., eradication of alternate hosts, rouging diseased plants, instituting fallow periods between plantings, and strategic plantings that avoid buildup of BGMV inoculum or the whitefly vector) may enable production of tepary bean in those regions that experience moderate to severe BGMV epidemics. 


\section{Breeding, Cultivars, Rootstocks, \& Germplasm Resources}

\section{Literature Cited}

Beebe, S.E. and M. Pastor-Corrales. 1991. Breeding for disease resistance, p. 561-610. In: A. van Schoonhoven and O. Voysest (eds.). Common beans: Research for crop improvement. CAB Intl., Wallingford, U.K.

Drijfhout, E. and W.J. Blok. 1987. Inheritance of resistance to Xanthomonas campestris pv. phaseoli in tepary bean (Phaseolus acutifolius). Euphytica 36:803-808.

Galvez, G.E. and F.J. Morales. 1989. Whiteflytransmitted viruses, p. 380-387. In: H.F. Schwartz and M. Pastor-Corrales (eds.). Bean production problems in the tropics. 2nd ed. Centro Internacional de Agricultura Tropical, Cali, Colombia.
Honma, S. 1956. A bean interspecific hybrid. J. Hered. 47:217-220.

Miklas, P.N., J.C. Rosas, J.S. Beaver, L. Telek, and G.F. Freytag. 1994. Field performance of select tepary bean germplasm for the tropics. Crop Sci. 34:1639-1644.

Morales, F.J. and S.P. Singh. 1993. Breeding for resistance to bean golden mosaic virus in an interracial population of Phaseolus vulgaris $\mathrm{L}$. Euphytica 67:59-63.

Nabhan, G.P. 1979. Tepary beans: The effects of domestication on adaptation to arid environments. Arid Lands Nwslt. 10:11-16.

Nabhan, G.P. and R.S. Felger. 1978. Teparies in southwestern North America. Econ. Bot. 32:2-19.

Parker, J.P. and T.E. Michaels. 1986. Simple genetic control of hybrid plant development in interspecific crosses between Phaseolus vulgaris L. and P. acutifolius A. Gray. Plant Breeding 97:315-323.

SAS. 1987. SAS/STAT guide for personal computers, 6th ed. SAS Inst., Cary, N.C.

Schoonhoven, A.V. and M.A. Pastor-Corrales (eds.). 1987. Standard system for the evaluation of bean germplasm. Centro Internacional de Agricultura Tropical, Cali, Colombia.

Scott, M.E. and T.E. Michaels. 1992. Xanthomonas resistance of Phaseolus interspecific cross selection confirmed by field performance. HortScience 27:348-350.

Thomas, C.V. and J.G. Waines. 1984. Fertile backcross and allotetraploid plants from crosses between tepary beans and common beans. J. Hered. 75:93-98. 